\title{
Recovery of Biomass Incinerated as Struvite-K Precipitates Followed Aluminium Removal
}

\author{
Endar Hidayat, Hadi Imran A. Halem, Yoshiharu Mitoma, Hiroyuki Harada* \\ Department of Environmental Science, Prefectural University of Hiroshima, Hiroshima, Japan \\ Email: ^ho-harada@pu-hiroshima.ac.jp
}

How to cite this paper: Hidayat, E., Halem, H.I.A., Mitoma, Y. and Harada, H. (2021) Recovery of Biomass Incinerated as Struvite-K Precipitates Followed Aluminium Removal. Green and Sustainable Chemistry, 11, 96-106. https://doi.org/10.4236/gsc.2021.113009

Received: July 15, 2021

Accepted: August 10, 2021

Published: August 13, 2021

Copyright (c) 2021 by author(s) and Scientific Research Publishing Inc. This work is licensed under the Creative Commons Attribution International License (CC BY 4.0).

http://creativecommons.org/licenses/by/4.0/

(c) (i) Open Access

\begin{abstract}
Phosphorus $(\mathrm{P})$ and potassium $(\mathrm{K})$ are non-renewable materials and widely in many industries such as agricultural sectors. On the other hand, the demand of $\mathrm{P}$ and $\mathrm{K}$ as fertilizers increases which following global population. The nutrient source of $\mathrm{P}$ and $\mathrm{K}$ which get from biomass waste i.e. incinerated of activated sludge and coffee husk biochar, respectively. The present study was conducted recovery of $\mathrm{P}$ and $\mathrm{K}$ as struvite- $\mathrm{K}\left(\mathrm{KMgPO}_{4} \cdot 6 \mathrm{H}_{2} \mathrm{O}\right)$ precipitates. The results showed that aluminium was released simultaneously with $\mathrm{P}$ from incinerated activated sludge with precipitate of $\mathrm{Al}: \mathrm{P}$ of $1: 1, \mathrm{~K}: \mathrm{P}$ of 0.5 , and $\mathrm{Mg}: \mathrm{P}$ of 3. However, aluminium was inhibited to form struvite- $\mathrm{K}$. Then, we examined cation removal especially for removed $\mathrm{Al}$ by dissolved $0.5 \mathrm{M}$ $\mathrm{HNO}_{3}$ and the solution was mixed with $\mathrm{KH}_{2} \mathrm{PO}_{4}$ and $\mathrm{MgCl}_{2} \cdot 6 \mathrm{H}_{2} \mathrm{O}$ as source of $\mathrm{K}$ and $\mathrm{Mg}$, respectively. The results showed aluminium ( $\mathrm{Al}$ ) was removed with precipitate $\mathrm{K}: \mathrm{P}$ of 0.5 , and $\mathrm{Mg}: \mathrm{P}$ of 0.8 . This study was confirmed that recovery of biomass incinerated was successful as struvite- $\mathrm{K}$ and can be used as fertilizers.
\end{abstract}

\section{Keywords}

Struvite-K, Recovery of Biomass Waste, Coffee Husk, Sludge Waste, Precipitates

\section{Introduction}

Current population projections estimate the world population to reach between 9 and 10 billion by 2050 [1] [2]. Among other things, this will mean increases in food production to feed the growing population. Commercial fertilizers play an important role in our food system, and most of our phosphorus and potassium-based fertilizers are derived from mined sources.

Phosphorus (P) is a limited asset, and it is assessed that global reserve of 
phosphate rock must be mined economically somewhere between 50 and 100 years that usually is used in industry such as agricultural sectors [3] [4]. On the other hand, potassium is generally used to create fundamental fertilizers, since the contains cannot be replaced as a nutrients source for plants. The reserve is as much as the utilization in many years with current consumption rate. In 2014, 31 million tons of potassium compost $\left(\right.$ as $\left.\mathrm{K}_{2} \mathrm{O}\right)$ were applied around the world, with request expected to increment by about 3\% each year [5]. Moreover, potassium is mined as mineral in limited number of countries, for example, Canada, Russia, Belarus and China [6] [7]. In any case, the cost of the potassium changes as seen in February 2009 due to the supply side issue [8]. Subsequently, potassium recovery should be considered as well as phosphorus to supply and demand $\mathrm{K}$ and $\mathrm{P}$ as fertilizers.

Based on the above reasons, we should discover alternatives for phosphorus and potassium sources for expanding global food production. Current organic sources of phosphate like bone meal, and animal manure are insufficient so new advancements should be developed for sustainable phosphate recovery from other natural waste sources, such as from sewage solid sludge. The materials are created during wastewater treatment processes and are a source of phosphorus [9]. Approximately, 90\% of the P in wastewater is caught in the sewage sludge solids [10].

The sewage sludge solids are the most part organic, so the elemental analysis shows high levels of carbon, oxygen and hydrogen. In any case, the sludge cannot be used directly as a fertilizer, due to the presence of harmful heavy metals and other toxic compounds [11]. Therefore, treatment is required to make the solids safe and make the nutrients recoverable. One option for sludge treatment may be to use its energy content to digest sewage sludge to produce biogas. However, the volume of the residual materials is almost the same as the volume of the original sludge [12]. In addition, this system requires an additional process to separate the phosphorus remaining after digestion. Based on these deliberations, incineration has becoming popular as the final disposal process of sludge. The incineration of municipal solid waste sludge reduces the mass and volume by about $70 \%$ to $90 \%$, respectively [13]. However, after incineration, the nutrient constituents not only phosphorus but other heavy metals such as aluminium (Al). On the other hand, this process is not expensive, waste management easier and more efficient [11].

While potassium source is from coffee husk which contains from $0.4 \%$ to $3.7 \%$ [14], USDA [15] reported production of coffee husk of 380.55 million bags (60 kilogram/bag) since 50\% produced $1 \mathrm{~kg}$ of coffee bean [14]. So, this is potential issues for utilized this waste as nutrient sources for plants. Moreover, this waste might be contributed to environmental problems such as global warming issues. Global warming indicates a quick temperature increases which have been noticed around the world. This might result from discharge of greenhouse gases into the atmosphere during burning of biofuels and decomposition of organic matter. Because they release carbon dioxide $\left(\mathrm{CO}_{2}\right)$ or greenhouse gas. The 
scientists around the world have been working to reduce the greenhouse gas productions by storing carbon in the environment [16]. In addition, global warming can be diminished globally through the process of soil carbon sequestration. The pyrolysis of biomass wastes into biochar is a potential strategy of accomplishing carbon sequestration [17]. Biochar can be utilized as a device to alleviate current climatic change and accomplish sustainable development in the world.

The objectives of this experiment were to recover of phosphorus and potassium from activated sludge charcoal and coffee husk biochar, respectively as struvite- $\mathrm{K}$ precipitates with the formula $\mathrm{MgKPO}_{4}^{3-} \cdot 6 \mathrm{H}_{2} \mathrm{O}$. The struvite- $\mathrm{K}$ is gained attention in the world because the formula suited to supplying nutrients through soil on crop growth.

\section{Materials and Method}

\subsection{Materials}

Sodium hydroxide $(\mathrm{NaOH})$, acetic acid $\left(\mathrm{CH}_{3} \mathrm{COOH}\right)$ and magnesium chloride $\left(\mathrm{MgCl}_{2} \cdot 6 \mathrm{H}_{2} \mathrm{O}\right)$ were obtained from the Kanto Chemical Co. Inc (Tokyo/Japan). All chemicals and reagents were of analytical grade used with purification by dissolved of distilled water.

\subsection{Sample Preparation}

Activated sludge is obtained from wastewater treatment plant, Miyoshi city, Hiroshima Prefecture. We collected which have already to become carbonized by factory. Coffee husk was collected from previous of our studied [18]. The dried sample was crushed and passed through $4.75 \mathrm{~m} / \mathrm{m}$ sieve at $60^{\circ} \mathrm{C}$ for $24 \mathrm{~h}$ in oven. The muffle furnace (model F0100 Yamato, Japan) is used to make biochar with temperature $600^{\circ} \mathrm{C}$ for $2 \mathrm{~h}$. The biochar passes through a sieved $<1 \mathrm{~mm}$ and washed with distilled water, oven dry at $60^{\circ} \mathrm{C}$ for $24 \mathrm{~h}$ and sealed in a beaker for further studies. The characteristics of biochar were presented in Table 1.

\subsection{Phosphate and Potassium Extraction}

Activated sludge charcoal used for phosphate extraction. The concentration was used $\mathrm{NaOH}$ with concentration from $0.1,0.2,0.3,0.4$ and $0.5 \mathrm{M}$ for 24 hours. The samples were carried out with 1 gram in $50 \mathrm{~mL}$ of solution. While for potassium extraction used coffee husk biochar, we used $\mathrm{CH}_{3} \mathrm{COOH}$ with concentration from $1,2,3,4$ and $5 \mathrm{M}$ for 30 minutes. The sample was carried out with 0.25 gram in 50 $\mathrm{mL}$ of solution.

\subsection{Procedure of Precipitation}

The best results of phosphate and potassium extraction were used. $50 \mathrm{~mL}$ of

Table 1. Characteristics of coffee husk biochar.

\begin{tabular}{cccc}
\hline C-Total (\%) & Oxygen (\%) & N-Total $(\%)$ & CEC (meq/100 g) \\
\hline 57.81 & 24.40 & 0.88 & 52.67 \\
\hline
\end{tabular}


1000 ppm magnesium solution was added to fixed amount of obtained solution. Phosphate and potassium were added 20 and $50 \mathrm{~mL}$, respectively. The detailed of procedure in Figure 1 and Figure 2.

\subsection{Analytical Methods}

The concentrations of $\mathrm{PO}_{4}^{3-}$ were determined by standard method (Japan Industrial Standard method JIS KO 102). The concentration of potassium was measured using atomic absorption spectrophotometer (AA-6300, Shimadzu Kyoto, Japan). Cation exchange capacity (CEC) was extracted $1 \mathrm{M} \mathrm{NH}_{4} \mathrm{OAc} \mathrm{pH}$ 7. Morphology and chemical composition of crystal was measured by Scanning Electron Microscopy (SEM) with Energy Dispersive X-Ray Analysis (EDX) (JED-2300) (Shimadzu, Kyoto, Japan).

1) First precipitation

2) Cation removal for eliminated of aluminium to get struvite-K precipitates

We examined cation removal especially for removed Al to get pure struvite-K by dissolved $0.5 \mathrm{M} \mathrm{HNO}_{3}$ for 1 hour with ratio of $1 / 100$ of solid sample/liquid. $1000 \mathrm{ppm}$ of $50 \mathrm{~mL}$ of the potassium and magnesium solution from $\mathrm{KH}_{2} \mathrm{PO}_{4}$ and $\mathrm{MgCl}_{2} \cdot 6 \mathrm{H}_{2} \mathrm{O}$, respectively. The solution was adjusted to $\mathrm{pH} 11$ by $\mathrm{NaOH}$. The detailed procedure is in Figure 2.

\section{Results and Discussion}

\subsection{Phosphate Extraction}

Phosphate recovery from sewade sludge with alkaline conditions has been studied in some authors [19]. Alkaline extraction is a good alternative since it gives a phosphorus product with a lower metal contamination. Most metals are most insoluble in alkaline than in acids, and extraction with alkaline gives a phosphorus product with a lower contamination of metal [20]. However, the process of

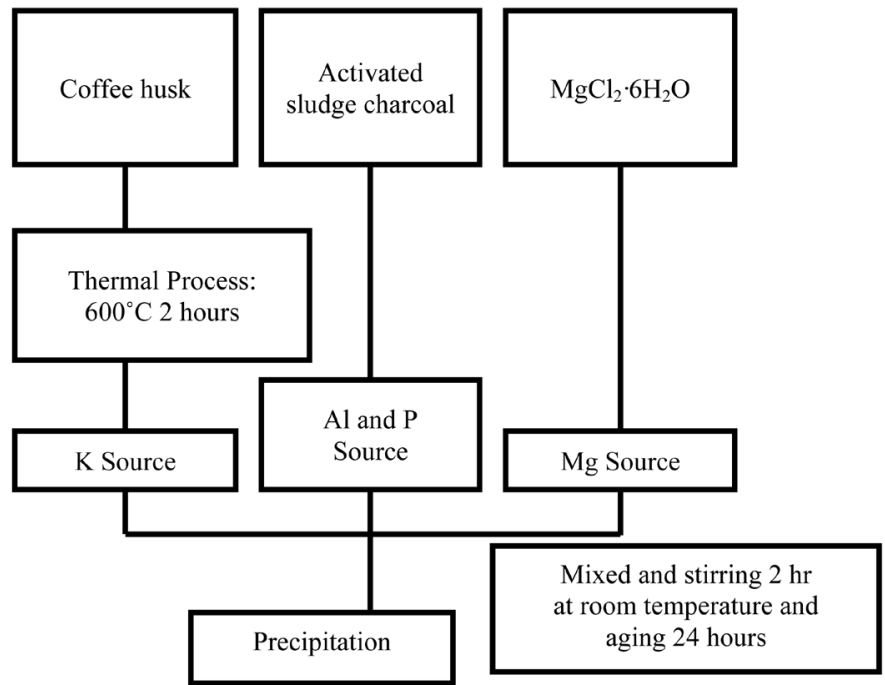

Figure 1. First precipitation, $\mathrm{Al}$ was released simultaneously with $\mathrm{P}$ from activated sludge charcoal. 


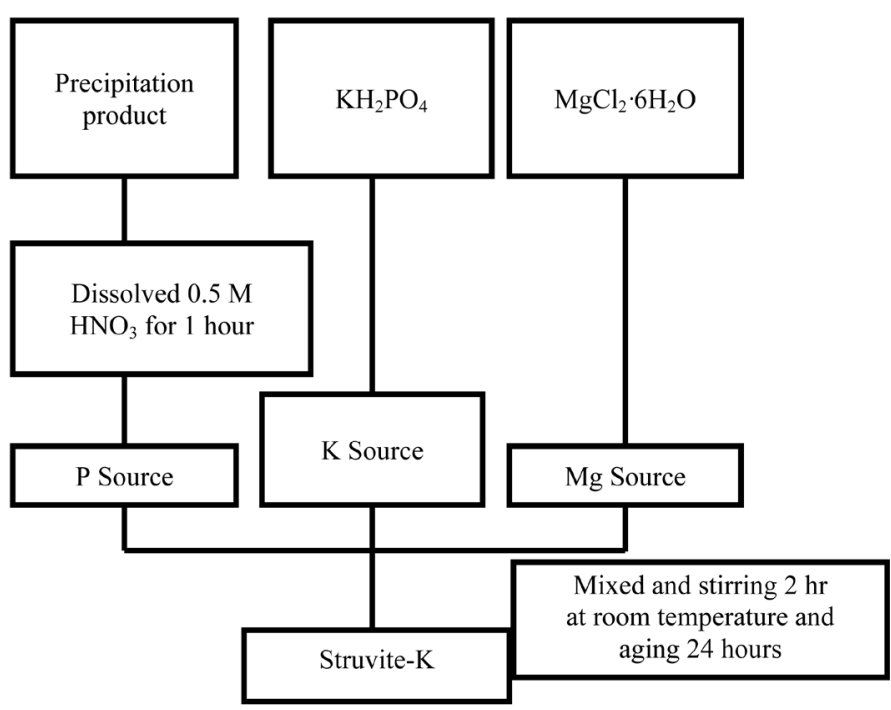

Figure 2. Procedure of cation removal especially Al to get Struvite-K.

extraction, aluminium was released which simultaneously with P. To confirm the release of aluminium, we examined extraction of activated sludge charcoal of $50 \mathrm{~mL}$ with $\mathrm{pH}$ of 12.8 . This $\mathrm{pH}$ value is considering low precipitation. However, we must adjust to $\mathrm{pH} 11$ by HCL [21].

To compete aluminium, we added $\mathrm{MgCl}_{2} \cdot 6 \mathrm{H}_{2} \mathrm{O}$ as magnesium source to adjusted molar Mg: $\mathrm{P}$ of 1:1 with formula in Equation (1), since this value is considering favorable for precipitation in many scientists. Stirring for 2 hours and aging for 24 hours then filtered. The solid precipitate was obtained then oven dried $60^{\circ} \mathrm{C}$. The results were obtained in Figure 3 and composition of precipitation as shown in Table 2.

$$
2 \mathrm{AlPO}_{4}+3 \mathrm{MgCl}_{2} \rightarrow \mathrm{Mg}_{3}\left(\mathrm{PO}_{4}\right)_{2}+2 \mathrm{AlCl}_{3}
$$

Table 3 presents the results of phosphate recovery under different concentration of $\mathrm{NaOH}$. It is found that the phosphate recovery increased, when concentration of $\mathrm{NaOH}$ increased from $0.1 \mathrm{M}$ to $0.3 \mathrm{M}$. Thereafter, the phosphate recovery decreases from $0.3 \mathrm{M}$ to $0.4 \mathrm{M}$ and slightly increased from $0.4 \mathrm{M}$ to $0.5 \mathrm{M}$. This is indicated that around this concentration phosphate recovery from activated sludge charcoal was effective. This is agreement with [22] that recovery of sludge in Karlskoga with sodium hydroxide reaches $90 \%$ of the phosphorus content.

\subsection{Potassium Extraction}

Potassium is a chemical element with the symbol $\mathrm{K}$ and atomic number 19. Potassium reacts rapidly with oxygen. Carboxylic acid is an organic acid that contains a carboxyl group and contains oxygen with formula $(\mathrm{C}(=\mathrm{O}) \mathrm{OH})$. The present study, we used acetic acid (AA). Acetic acid is the second simplest carboxylic acid (after formic acid). In the other hand, acetic acid is widely used bulk chemical and it can be used as green solvent that non-toxic in environment [23]. 


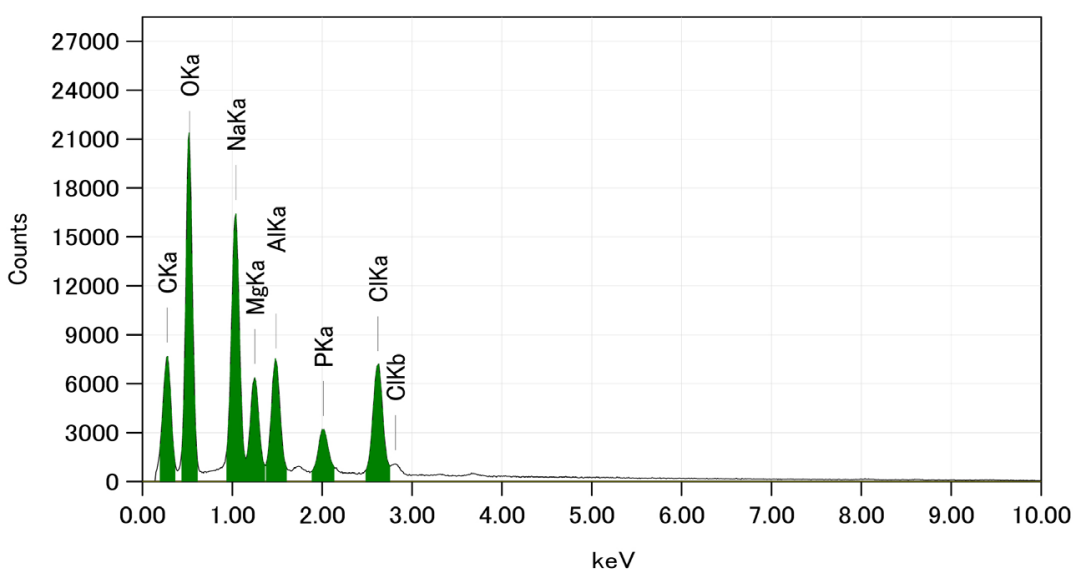

Figure 3. EDX results (extracted from activated sludge charcoal).

Table 2. Composition of precipitation (extracted from activated sludge charcoal).

\begin{tabular}{ccccccc}
\hline \multicolumn{7}{c}{ Composition (wt\%) } \\
\hline $\mathrm{C}$ & $\mathrm{O}$ & $\mathrm{Na}$ & $\mathrm{Mg}$ & $\mathrm{Al}$ & $\mathrm{P}$ & $\mathrm{Cl}$ \\
\hline 24.90 & 40.33 & 13.60 & 4.97 & 5.37 & 2.64 & 8.19 \\
\hline
\end{tabular}

Table 3. Concentration of different phosphate extraction.

\begin{tabular}{cccc}
\hline Extractants & Equilibrium time & Equilibrium $\mathrm{pH}$ & $\mathrm{PO}_{4}^{3-}$ \\
\hline $0.1 \mathrm{M} \mathrm{NaOH}$ & 24 hours & 11.6 & 400 \\
$0.2 \mathrm{M} \mathrm{NaOH}$ & 24 hours & 12.3 & 424 \\
$0.3 \mathrm{M} \mathrm{NaOH}$ & 24 hours & 12.8 & 2920 \\
$0.4 \mathrm{M} \mathrm{NaOH}$ & 24 hours & 13.1 & 2620 \\
$0.5 \mathrm{M} \mathrm{NaOH}$ & 24 hours & 13.2 & 2730 \\
\hline
\end{tabular}

Acetic acid is acidic character because release of the proton $\left(\mathrm{H}^{+}\right)$. Furthermore, acetic acid is in the carboxyl group (-COOH) can separate from the molecule by ionization in Equation (2) and reacts with cation such as potassium with formula in Equation (3).

$$
\begin{gathered}
\mathrm{CH}_{3} \mathrm{COOH} \rightarrow \mathrm{CH}_{3} \mathrm{CO}_{2}^{-}+\mathrm{H}^{+} \\
\mathrm{K}_{2} \mathrm{O}+\mathrm{CH}_{3} \mathrm{COOH} \rightarrow \mathrm{CH}_{3} \mathrm{COOHK}+\mathrm{H}_{2} \mathrm{O}
\end{gathered}
$$

Table 4 presents the recovery of potassium under different concentration of acetic acid (AA). It is found that the potassium recovery fluctuating in all concentrations. The lower results in $4 \mathrm{M} \mathrm{CH}_{3} \mathrm{COOH}$ with concentration of $26 \mathrm{mg} / \mathrm{L}$ while the higher in $5 \mathrm{M} \mathrm{CH}_{3} \mathrm{COOH}$ with concentration of $1891 \mathrm{mg} / \mathrm{L}$. This is indicated that higher concentration of acetic acid can easily react with potassium.

\subsection{First Precipitation Process}

The present study, we examined the reaction conditions for the first precipitation. Experimental conditions we conducted in glass and stirring for 2 hours. The solution is from $50 \mathrm{~mL}$ of $1000 \mathrm{ppm}$ magnesium from $\mathrm{MgCl}_{2} \cdot 6 \mathrm{H}_{2} \mathrm{O}$. The 
Table 4. Concentration of different potassium extraction.

\begin{tabular}{cccc}
\hline Extractants & Equilibrium time & Equilibrium $\mathrm{pH}$ & $\mathrm{K}^{+}$ \\
\hline $1 \mathrm{M} \mathrm{CH}_{3} \mathrm{COOH}$ & 30 minutes & 2.2 & 122 \\
$2 \mathrm{M} \mathrm{CH}_{3} \mathrm{COOH}$ & 30 minutes & 2.1 & 58 \\
$3 \mathrm{M} \mathrm{CH}_{3} \mathrm{COOH}$ & 30 minutes & 2.0 & 190 \\
$4 \mathrm{M} \mathrm{CH}_{3} \mathrm{COOH}$ & 30 minutes & 1.8 & 26 \\
$5 \mathrm{M} \mathrm{CH}_{3} \mathrm{COOH}$ & 30 minutes & 1.7 & 1891 \\
\hline
\end{tabular}

phosphate solution is added $20 \mathrm{~mL}$ from $0.3 \mathrm{M} \mathrm{NaOH}$ extractants as shown in Table 3. While for potassium solution is added $50 \mathrm{~mL}$ from $5 \mathrm{M} \mathrm{CH}_{3} \mathrm{COOH}$ as shown in Table 4 . However, the aluminium was released simultaneously with $\mathrm{P}$ from activated sludge charcoal which has described in above as shown in Figure 3. While for this precipitation we added potassium to make composition of struvite- $\mathrm{K}\left(\mathrm{MgKPO}_{4} \cdot 6 \mathrm{H}_{2} \mathrm{O}\right)$ as shown in Figure 4.

The results show that the aluminium content is $0.85 \mathrm{wt} \%$ (Table 5) which lower than Figure 3 is $5.37 \%$ (EDX results from activated sludge charcoal). This is indicated that potassium can compete with aluminium in precipitation with precipitate of $\mathrm{Al}$ : P of 1, Mg: P of 3 and $\mathrm{K}$ : $\mathrm{P}$ of 0.5 (in mol/l). Calculated from wt $\%$ to $\mathrm{mol} / \mathrm{l}$ in Equation (4).

$$
\mathrm{wt} \% / \mathrm{Fw}
$$

Morphology of precipitation as shown in Figure 5. Seen that needle-like mixed with tetrahedral structure, indicated that aluminium reacts with phosphate to become aluminium phosphate precipitates [24]. However, to get pure of struvite- $\mathrm{K}$ we must examine or release of aluminium in solid precipitation. On the other hand, benefit of aluminium is can be used as coagulate of organic matters which occurs of eutrophication [25]. Moreover, if aluminium can directly use in soil as fertilizer, it may have negative effect on plant growth [26].

\subsection{Cation Removal to Get Struvite-K Precipitates}

After the first precipitation, we examined cation removal especially to removed aluminium from precipitation product to get struvite- $\mathrm{K}$ by dissolved $0.5 \mathrm{M}$ $\mathrm{HNO}_{3}$ with reacts with aluminium with formula in Equation (5):

$$
\mathrm{Al}_{2} \mathrm{O}_{3}+6 \mathrm{HNO}_{3} \rightarrow 2 \mathrm{Al}\left(\mathrm{NO}_{3}\right)_{3}+3 \mathrm{H}_{2} \mathrm{O}
$$

$\mathrm{KH}_{2} \mathrm{PO}_{4}$ and $\mathrm{MgCl}_{2} \cdot 6 \mathrm{H}_{2} \mathrm{O}$ as potassium and magnesium sources, respectively as solution of struvite- $\mathrm{K}$ precipitates. The solution was adjusted to $\mathrm{pH} 11$ by $\mathrm{NaOH}$. The results show in Figure 6 with chemical composition in Table 6.

Based on Figure 6, the aluminium was successfully removed from solid precipitation. This is indicated that $\mathrm{HNO}_{3}$ was effectively used to release of cation especially aluminium with precipitate of K: $\mathrm{P}$ of 0.5 and Mg: $\mathrm{P}$ of 0.8 . Furthermore, struvite- $\mathrm{K}$ precipitates during processing which fall to become sediment as shown in Figure 7. And if have dried, struvite- $\mathrm{K}$ precipitates can be seen as crystal through SEM images as shown in Figure 8. The shape is needle-like which have reported in some experimental works [27] [28]. 


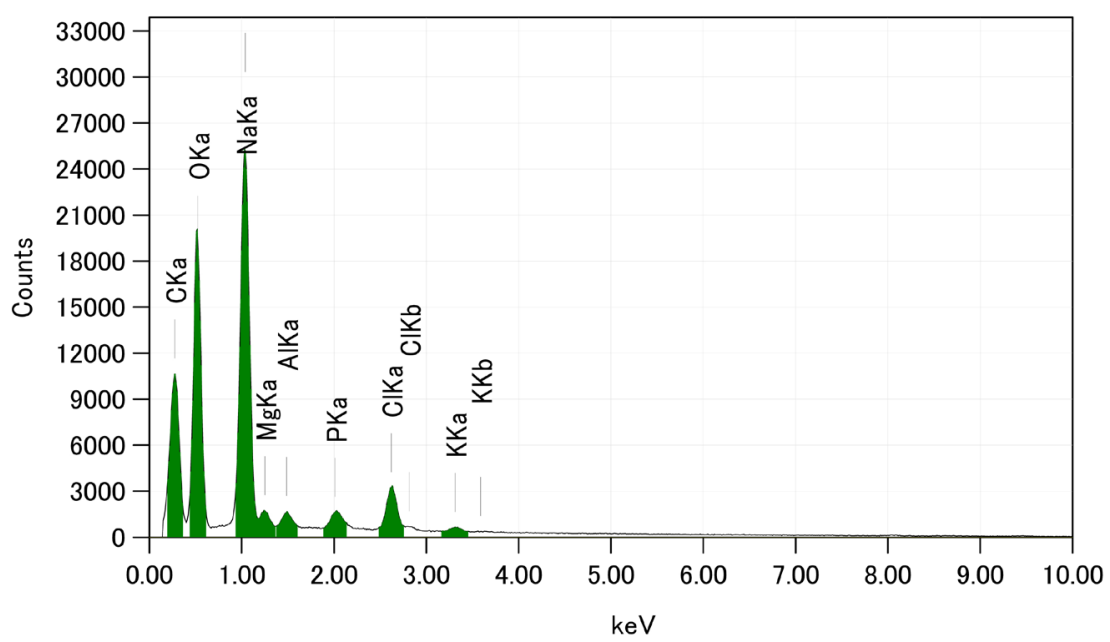

Figure 4. EDX results, first precipitation.

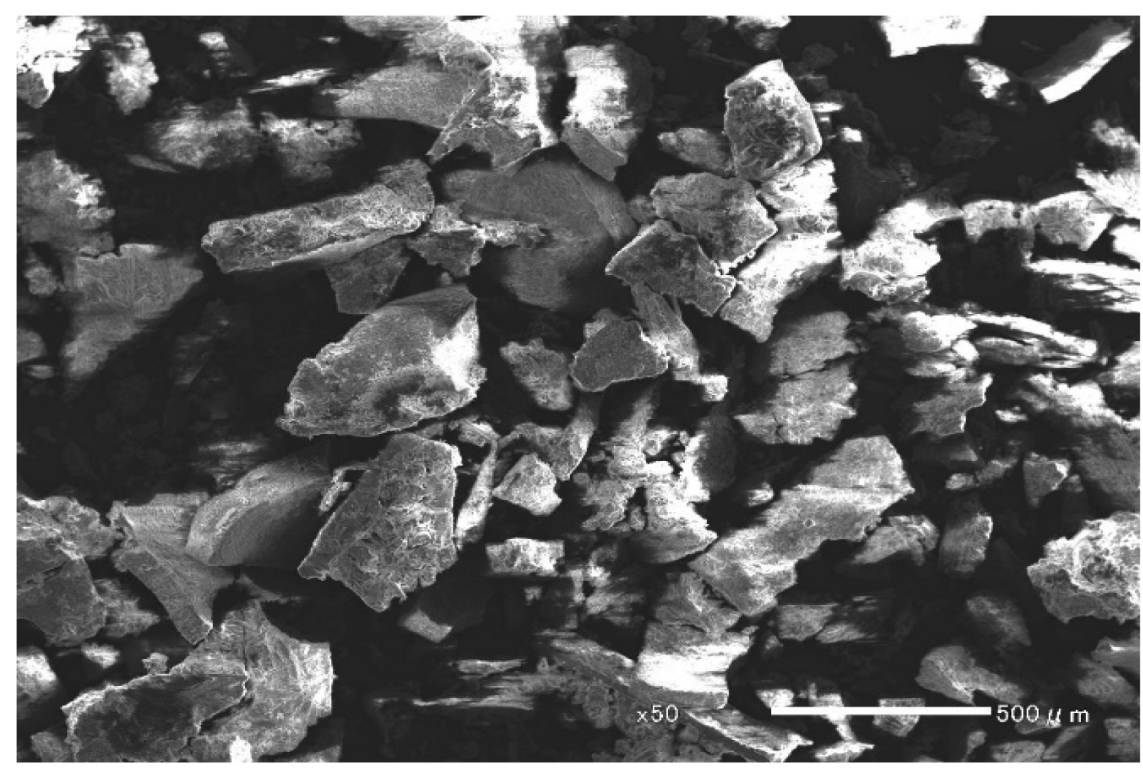

Figure 5. SEM images in first precipitation.

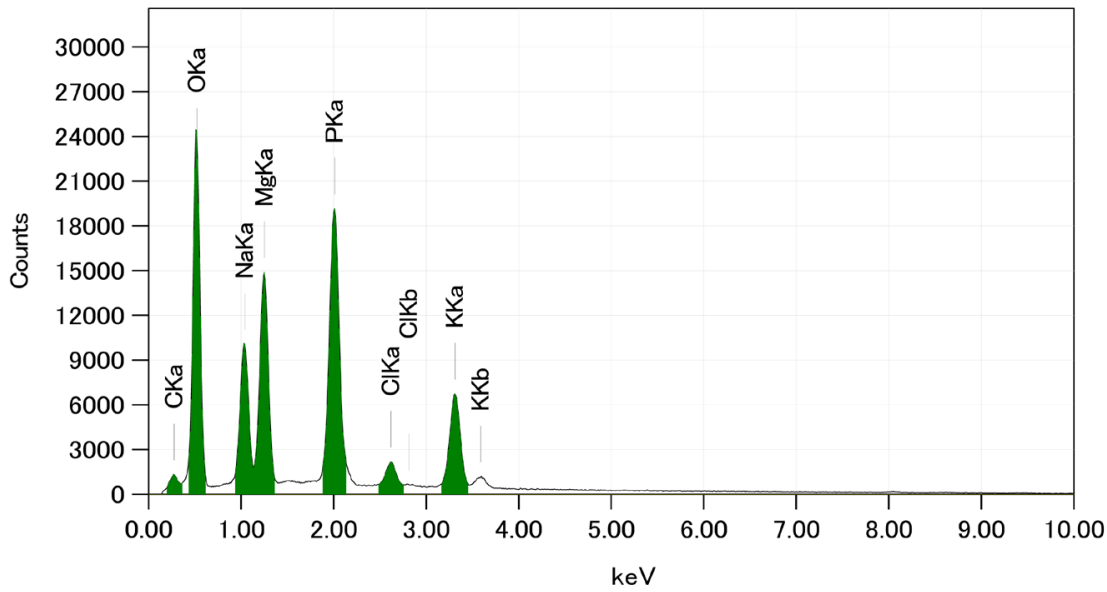

Figure 6. EDX results from cation removal as struvite-K precipitates. 


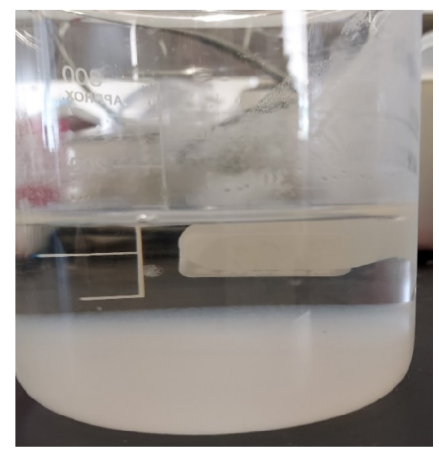

Figure 7. Images of struvite-K precipitate in aging process.

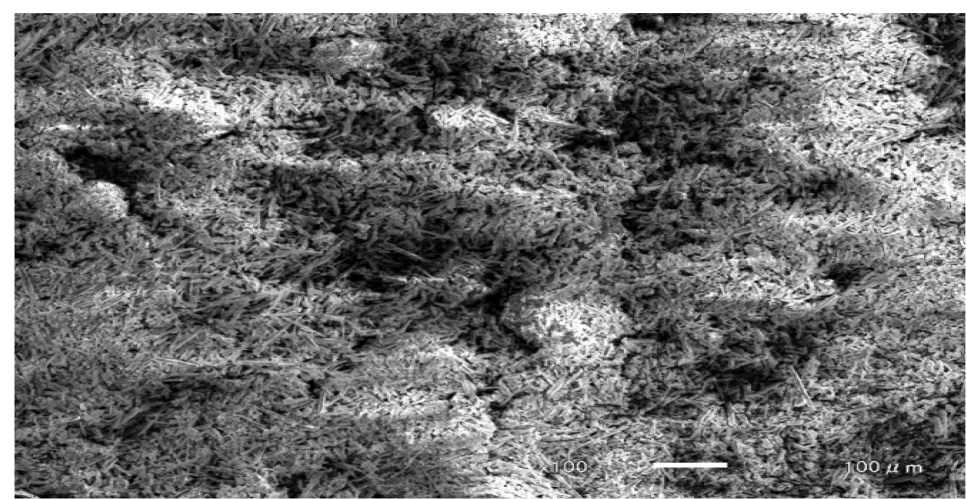

Figure 8. SEM images of struvite-K precipitates.

Table 5. Composition of first precipitation.

\begin{tabular}{cccccccc}
\hline \multicolumn{7}{c}{ Composition (wt\%) } \\
\hline $\mathrm{C}$ & $\mathrm{O}$ & $\mathrm{Na}$ & $\mathrm{Mg}$ & $\mathrm{Al}$ & $\mathrm{P}$ & $\mathrm{Cl}$ & $\mathrm{K}$ \\
\hline 27.27 & 40.63 & 23.42 & 2.20 & 0.82 & 1.02 & 4.06 & 0.55 \\
\hline
\end{tabular}

Table 6. EDX results from cation removal as struvite-K precipitates.

\begin{tabular}{ccccccc}
\hline \multicolumn{7}{c}{ Composition (wt\%) } \\
\hline $\mathrm{C}$ & $\mathrm{O}$ & $\mathrm{Na}$ & $\mathrm{Mg}$ & $\mathrm{P}$ & $\mathrm{Cl}$ & $\mathrm{K}$ \\
\hline 3.53 & 45.47 & 8.83 & 11.12 & 18.31 & 2.03 & 10.71 \\
\hline
\end{tabular}

\section{Conclusion}

Recovery of phosphorus and potassium from biomass incinerated was investigated. We found that aluminium was released simultaneously with $\mathrm{P}$ from activated sludge charcoal. To eliminate aluminium, we examined by dissolving 0.5 $\mathrm{M} \mathrm{HNO}_{3}$ and the solution was mixed with $\mathrm{KH}_{2} \mathrm{PO}_{4}$ and $\mathrm{MgCl}_{2} \cdot 6 \mathrm{H}_{2} \mathrm{O}$ as source of potassium and magnesium, respectively as struvite- $\mathrm{K}$ precipitates.

\section{Acknowledgements}

The author (E.H.) would like to thanks MEXT Scholarship for funding while studying in Prefectural University of Hiroshima, Japan. 


\section{Conflicts of Interest}

The authors declare no conflicts of interest regarding the publication of this paper.

\section{References}

[1] Pew Research Center (2014) Attitudes about Aging: A Global Perspective. https://www.pewresearch.org/global/2014/01/30/attitudes-about-aging-a-global-per spective/

[2] UN News Centre (2050) World Population Projected to Reach 9.6 Billion by. http://www.un.org/apps/news/story.asp?NewsID=45165\#.VPd1E0LVmoU

[3] Jordaan, E.M., Ackerman, J. and Cicek, N. (2010) Phosphorus Removal from Anaerobically Digested Swine Wastewater through Struvite Precipitation. Water Science and Technology, 61, 3228-3234. https://doi.org/10.2166/wst.2010.232

[4] Muster, T.H., Douglas, G.B., Sherman, N., Seeber, A., Wright, N. and Güzükara, Y. (2013) Towards Effective Phosphorus Recycling from Wastewater: Quantity and Quality. Chemosphere, 91, 676-684. https://doi.org/10.1016/j.chemosphere.2013.01.057

[5] Robert, M. and Caterina, B. (2015) World Fertilizer Trends and Outlook to 2018. Food and Agriculture Organization of the United States (FAO), Rome, 66.

[6] Jasinski, S.M. (2018) Phosphate Rock. Mineral Commodity Summaries, USGS, Reston, 122-123.

[7] Orris, G.J., Cocker, M.D., Dunlap, P., Wynn, J., Spanski, G.T., Briggs, D.A. and Gass, L. (2014) Potash-A Global Overview of Evaporate-Related Potash Resources, Including Spatial Data-Bases of Deposits, Occurrences, and Permissive Tracts. Scientific Investigations Report. 2010-5090-S. U.S Geological Survey, Reston. https://doi.org/10.3133/sir20105090S

[8] Yager, D.B. (2016) Potash-A Vital Agricultural Nutrient Sourced from Geologic Deposits. Open-File Report 2016-1167, U.S. Geological Survey, Reston, 28. https://doi.org/10.3133/ofr20161167

[9] Kelessidis, A. and Stasinakis, A.S. (2012) Comparative Study of the Methods Used for Treatment and Final Disposal of Sewage Sludge in European Countries. Waste Management, 32, 1186-1195. https://doi.org/10.1016/j.wasman.2012.01.012

[10] Blöcher, C., Niewersch, C. and Melin, T. (2012) Phosphorus Recovery from Sewage Sludge with a Hybrid Process of Low-Pressure Wet Oxidation and Nanofiltration. Water Resources, 46, 2009-2019. https://doi.org/10.1016/j.watres.2012.01.022

[11] Cieślik, B.M., Namiesnik, J. and Konieczka, P. (2015) Review of Sewage Sludge Management: Standards, Regulations and Analytical Methods. Journal of Cleaner Production, 90, 1-15. https://doi.org/10.1016/j.jclepro.2014.11.031

[12] Biplob, K.B., Katsutoshi, I., Hiroyuki, H., Keisuke, O. and Hidetaka, K. (2009) Leaching of Phosphorus from Incinerated Sewage Sludge Ash by Means of Acid Extraction Followed by Adsorption on Orange Waste Gel. Journal of Environmental Sciences, 21, 1753-1760. https://doi.org/10.1016/S1001-0742(08)62484-5

[13] Kosson, D.S., van der Sloot, H.A. and Eighmy, T.T. (1996) An Approach for Estimation of Contaminant Release during Utilization and Disposal of Municipal Waste Combustion Residues. Journal of Hazardous Materials, 47, 43-75. https://doi.org/10.1016/0304-3894(95)00109-3

[14] Zoca, S.M., Penn, C.J., Rosolem, C.A., Alves, A.R., Neto, L.O. and Martins, M.M. 
(2014) Coffee Processing Residues as a Soil Potassium Amendment. International Journal Recycle Organic Waste and Agriculture, 3, 155-165. https://doi.org/10.1007/s40093-014-0078-7

[15] United States Department of Agriculture (USDA) (2020) Coffee: World Markets and Trade. Foreign Agricultural Service. Global Market Analysis.

[16] Lehmann, J., Gaunt, J. and Rondon, M. (2006) Bio-Char Sequestration in Terrestrial Ecosystems-A Review. Mitigation Adaptation Strategies for Global Change, 11, 403-427. https://doi.org/10.1007/s11027-005-9006-5

[17] Sohi, S.P., Krull, E., Lopez-Capel, E. and Bol, R. (2010) A Review of Biochar and Its Use and Function in Soil. Advances in Agronomy, 105, 47-82.

https://doi.org/10.1016/S0065-2113(10)05002-9

[18] Endar, H., Asmak, A., Gusmini, G., Masuda, T. and Hiroyuki, H. (2020) Evaluate of Coffee Husk Compost. International Journal Food Agriculture and Natural Resources, 1, 37-43. https://doi.org/10.46676/ij-fanres.v1i1.8

[19] Stark, K. and Hultman, B. (2003) Phosphorus Recovery by One or Two-Step Technology with Use of Acids and Bases. Proceedings of IWA Specialist Conference Biosolids 2003 Wastewater Sludge as a Resource, Trondheim, 23-25 June 2003, 281-288.

[20] Levlin, E., Löwén, M. and Stark, K. (2003) Phosphorus Recovery from Sludge Incineration Ash and Supercritical Water Oxidation Residues with Use of Acids and Bases. Proceedings of a Polish-Swedish Seminar, Wisła, 25-28 October 2003, 19-28.

[21] Harada, H., Katayama, Y., Afriliana, A., Inoue, M., Teranaka, R. and Mitoma, Y. (2017) Effects of Co-Existing Ions on the Phosphorus Potassium Ratio of the Precipitate Formed in the Potassium Phosphate Crystallization Process. Journal of Environmental Protection, 8, 1424-1434. https://doi.org/10.4236/jep.2017.811086

[22] Stendahl, K. and Jäfverström, S. (2004) Recycling of Sludge with the Aqua Reci Process. Water Science and Technology, 49, 233-240.

https://doi.org/10.2166/wst.2004.0652

[23] Yoneda, N., Kusano, S., Yasui, M., Pujado, P. and Wilcher, S. (2001) Recent Advances in Processes and Catalysts for the Production of Acetic Acid. Applied Catalysis A: General, 221, 253-265. https://doi.org/10.1016/S0926-860X(01)00800-6

[24] Devamani, R., Hepzi, P. and Alagar, M. (2012) Synthesis and Characterization of Aluminium Phosphate Nanoparticles. Journal of Applied Sciences and Engineering Research, 1, 769-775. https://doi.org/10.6088/ijaser.0020101078

[25] Amirtharajah, A. and O'Melia, C.R. (1990) Coagulation Processes: Destabilization, Mixing and Flocculation. In: Pontius, F.W., Ed., Water Quality and Treatment, 4th Edition, McGraw-Hill, New York, 269-365.

[26] Teresa, M.P. (2001) Effect of Aluminium on Plant Growth and Metabolism. Review. Acta Biochimica Polonica, 48, 673-686. https://doi.org/10.18388/abp.2001 3902

[27] Chauhan, C.K., Vyas, P.M. and Joshi, M.J. (2011) Growth and Characterization of Struvite-K Crystals. Crystal Research and Technology, 46, 187-194. https://doi.org/10.1002/crat.201000587

[28] Satoshi, Y., Ohura, S., Harada, H., Akagi, K., Mitoma, Y., Kawakita, H. and Biplob, K.B. (2013) Simultaneous Crystallization of Phosphate and Potassium as Magnesium Potassium Phosphate Using Bubble Column Reactor with Draught Tube. Journal of Environmental Chemical Engineering, 1, 1154-1158.

https://doi.org/10.1016/j.jece.2013.08.032 